\title{
Righting Australia's Vertical Fiscal Imbalance: Transferring Public Hospital Funding as an Option for Reform
}

\author{
Richard Eccleston ${ }^{1}$
}

\begin{abstract}
Vertical Fiscal Imbalance (VFI) is the root cause of intergovernmental conflict in the Australian federation, and un-remedied will limit the dividends of any revitalised Council of Australian Governments. The paper argues the while the GST has been an effective growth tax, it has exacerbated Australia's VFI and is unlikely to yield sufficient revenues to meet the expenditure pressures confronting the States. The paper suggests that transferring the funding of public hospitals to the Commonwealth will enhance the sustainability of State public finances and reduce the VFI.
\end{abstract}

\section{Introduction}

Reforming Australian federalism has become a clear priority for the Rudd Government. While a more negotiated and consensual style of federalism has the potential to deliver significant dividends, this article argues that intergovernmental relations in Australia will remain prone to conflict as long as the States remain financially dependent on the Commonwealth. Given this premise, the paper examines the extent of the vertical fiscal imbalance (VFI) in the Australian federation and whether the States have access to, and control over, sufficient revenues to deliver the services and infrastructure for which they are constitutionally responsible. The article throws some light on these issues by evaluating whether the post-GST Intergovernmental Agreement (IGA) of 1999 has enhanced the State's fiscal and budgetary capacity. Having provided an overview of developments in federal financial relations, the second half of the article assesses the implications of a federal takeover of public hospital funding, and concludes in favour of such a takeover.

\section{The 1998 GST Agreement and its aftermath}

The most surprising aspect of the Howard Government's 1998 GST (A New Tax System or ANTS) package was the fact that all GST revenue was to be allocated to the States in lieu of existing Revenue Replacement Grants (introduced after

\footnotetext{
1 The School of Government, the University of Tasmania, Richard.Eccleston@utas.edu.au. I would like to thank Agenda's editor and two anonymous referees for their detailed comments on an earlier draft of this article, as well as feedback from various colleagues in The School of Government of the University of Tasmania. The usual caveats apply. The analysis presented in this article served as the basis for an invited submission to the Senate Select Committee on State Government Financial Management.
} 
the $1997 \mathrm{Ha}$ Case), general Financial Assistance Grants and a host of other indirect State taxes (Eccleston 2004: 137; Hamill 2006: ch. 5). In many ways, this revenue-sharing strategy was a political masterstroke. The prospects of accessing a growth tax ensured the support of State Premiers. Moreover, the Intergovernmental Agreement (IGA) and the commitment therein that the proposed GST could only be altered with the unanimous support of both State and Federal Governments reassured voters that the GST rate would not subsequently be increased (Costello 1998). Yet, in terms of federalism, the most significant aspect of the ANTS package and the subsequent IGA was that it promised to put State finances on a more secure footing. This point was made by the Treasurer, Peter Costello, when he confidently predicted that 'The GST will provide the States and Territories with a secure source of revenue that grows as the economy grows to secure funding for essential services, such as schools, hospitals and roads' (as quoted in Hamill 2006: 126).

In many ways, the GST has lived up to the Howard Government's claims as GST revenues distributed to the States have risen by an average of 8.9 per cent per annum in nominal terms over the seven years since its introduction (Table 1). In fact, buoyant economic conditions and strong domestic consumption over the period have resulted in GST revenues exceeding predictions made when the tax was first proposed. For example, GST revenue in 2007-08 alone is projected to be 7.6 per cent higher than forecast under the IGA (Commonwealth of Australia 2007).

However, this aggregate data obscures a number of subtle, yet significant, impacts which the IGA has had on intergovernmental financial relations. The GST may, as Treasurer Costello promised, have provided a secure source of revenue for the States, but this does not necessarily mean that the State's funding base is adequate or that the IGA has necessarily enhanced the State's fiscal capacity, or their ability to control their own taxing and spending priorities (Hamill 2006: 75).

Table 1: Growth in GST to the States 2000-2007

\begin{tabular}{lccccccc}
\hline 2000-01 & $\mathbf{2 0 0 6 - 0 7}$ & Increase \$ & Increase \% & $\begin{array}{c}\text { Annual Avg. } \\
\text { Increase \% }\end{array}$ & $\begin{array}{c}\text { GSP } \\
\text { Avg. Annual } \\
\text { Increase \% }\end{array}$ & $\begin{array}{c}\text { State GST } \\
\text { 'windfall' }\end{array}$ \\
\hline NSW & $\mathbf{7 2 5 7 . 6 0}$ & 10937.5 & 3679.90 & 50.7 & 7.2 & 6.8 & $+0.4 \%$ \\
VIC & 5099.30 & 8588.0 & 3488.70 & 68.4 & 9.8 & 6.5 & $+3.3 \%$ \\
QLD & 4658.20 & 8092.2 & 3434 & 73.7 & 10.5 & 7.8 & $+2.7 \%$ \\
WA & 2374.60 & 3968.1 & 1593.50 & 67.1 & 9.6 & 14.5 & $-4.9 \%$ \\
SA & 2278.90 & 3604.9 & 1326 & 58.2 & 8.3 & 5.5 & $+2.8 \%$ \\
TAS & 988.1 & 1567.6 & 579.5 & 58.6 & 8.4 & 10.3 & $-1.9 \%$ \\
ACT & 472.6 & 778.3 & 305.7 & 64.7 & 9.2 & 9.7 & $-0.5 \%$ \\
NT & 1225.60 & 2015.3 & 789.7 & 64.4 & 9.2 & 8.9 & $+0.3 \%$ \\
TOTAL & 24354.90 & 39551.90 & 15197.00 & 62.4 & 8.9 & 8.6 & $+0.3 \%$ \\
\hline
\end{tabular}

(Source: ABS 2007 - Cat. 5220) 
In 2004 Treasurer Costello claimed the GST had delivered a windfall to the States 'over and above previous funding arrangements' (Costello 2004). While it is hard to refute the fact that the GST has grown faster than anticipated, it is also easy to overstate the fiscal dividends it has delivered. Firstly, strong economic growth in recent years means that the swag of State taxes and duties which were replaced under the IGA would also have grown more quickly than forecast. Given this, it is slightly misleading to represent the growth in the GST tax base as being a windfall (Collins and Warren 2007). Indeed, it can be argued that Commonwealth actually appropriated a portion of this windfall when it unilaterally decided to phase out balancing payments to the States two years ahead of schedule (Hamill 2006: 174). Similarly, the growth in GST revenue to Western Australia, Tasmania and the ACT actually lagged behind the increase in Gross State Product over the period (Table 1).

Another way of benchmarking the performance of the GST tax base is to compare its relative performance to other federal taxes. As Figure 1 indicates, GST revenues have not grown as a percentage of total federal revenue over the period and, with the exception of the economic slowdown of 2001-02, federal income taxes (despite significant cuts to personal income rates over the period) have tended to increase more rapidly than GST revenue. This finding is consistent with broader claims in the public finance literature that broad-based consumption taxes, such as the GST, deliver stable rather than spectacular revenue growth (Ebrill 2001). In short, the budgetary position of the States has improved over the period of the IGA, but not to the same extent as federal finances and, as a result, the Commonwealth is in a stronger position to fund high-cost public services such as public hospitals.

Figure 1: The growth in GST revenue relative to other federal taxes 2000-07

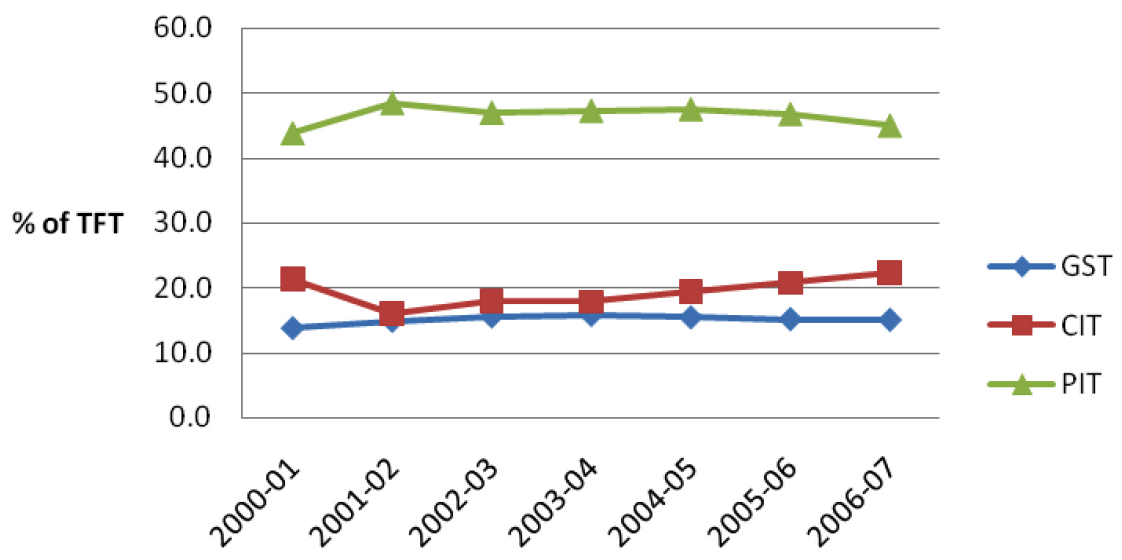

Fiscal Year

(Source: ABS 2007 - Cat. 5506) 
The second important consequence of the IGA is that it has eroded the fiscal capacity of the States because, with the IGA's abolition of various indirect taxes and duties and well as the Revenue Replacement Payments, the States are increasingly dependent on revenue sources over which they have no control. For example, in 1999-2000 (the year prior to the IGA) States raised 40 per cent of their total operating income from own-source taxes, whereas by 2005-06 this figure had fallen to 33 per cent (Hamill 2006: 150). The 2006 Ministerial Council agreement to abolish a second tranche of States taxes (with compensation) will erode the State tax base further (Commonwealth of Australia 2007).

\section{State Finances in the $21^{\text {st }}$ century}

The IGA granted the States access to an efficient growth tax in the form of the GST, which was to be administered by the Commonwealth. Given this context we would expect the States to gradually reduce their reliance on existing own-source taxes given both the electoral benefits of cutting taxes combined with widespread recognition that many of the remaining State taxes were administratively complex and economically inefficient (Smith 2007; Freebairn 2002). Yet an analysis of State taxation over the period clearly defies such predictions.

Table 2: Key trends in state taxation 2000-06

\begin{tabular}{lrrrrr}
\hline Column1 & 2000-01 & 2005-06 & Increase \$ & Increase \% & $\begin{array}{r}\text { Annual } \\
\text { Increase \% }\end{array}$ \\
\hline Gambling Machine Tax & 2071 & 2839 & 768 & $37.1 \%$ & $7.4 \%$ \\
Payroll tax & 9503 & 13087 & 3584 & $37.7 \%$ & $7.5 \%$ \\
Property tax & 7406 & 13784 & 6378 & $86.1 \%$ & $17.2 \%$ \\
Total State Rev & 32679 & 44235 & 11556 & $35.3 \%$ & $7.0 \%$ \\
\hline
\end{tabular}

(Source: ABS 2007 - Cat. 5220)

State taxation increased by over 35 per cent in nominal terms (or \$11.55 billion) over the period between mid-2000 and mid-2006. Of even greater significance is the specific composition of this increase and the fact that it was largely driven by the rapid growth in State property taxes on the back of a booming property market (particularly between 2000 and 2003). Over this period, revenues from land taxes and conveyancing charges on real-estate transactions increased by 28 per cent per annum. Even averaging this growth over the six years for which data is available, the housing boom contributed over 55 per cent of total State revenue growth, with payroll and gambling taxes accounting for most of the remainder. The problem for State public finances is that this property-tax windfall was the dividend of unsustainable housing boom, a reality borne out by the fact that such revenues have declined in real terms since 
2003-04 as real-estate prices have stabilised and the volume of property transactions has fallen (Productivity Commission 2004). ${ }^{2}$

Narrowly based taxes are inevitably inefficient and volatile. Periods of exceptional revenue growth, such as the States experienced during the early years of the decade, are a boon for public finances just so long as they are not committed to recurrent expenditure, and herein lies the budget challenge confronting the States. State governments were able to achieve modest cash surpluses (and retire State debt) at the height of the property boom. However, many States are now struggling to maintain a cash surplus as the growth in own-source revenues slows.

According to the latest Commonwealth Budget Papers (2008b), aggregate net State debt for the total non-financial public sector (which combines general government and public non-financial corporations) will increase from 1.1 per cent of GDP in 2005-06 to 5.7 per cent in 2009-10. These financial pressures will be compounded by the fact that total Commonwealth funding to the States (both GST revenue and Special Purpose Payments) will grow at a pedestrian 5.5 per cent over the forward estimates contained in the federal budget papers, significantly slower than in 8.2 per cent experienced in recent years (Commonwealth of Australia 2008b). When combined with unprecedented challenges in relation to health, education and infrastructure funding, it is not surprising that State Treasurers are once again trying to devise politically palatable ways of expanding their tax base and increasing revenue. ${ }^{3}$ In summary, the IGA increased total funding available to the States (budget capacity); however, this increase in funding has largely failed to keep pace with rising expenditure pressures. As a result, State governments have been forced to increase their reliance on their own-source taxation in addition to their growing transfers from the Commonwealth under the IGA. Regrettably, the tax base on which the States are becoming more reliant is even narrower and less efficient than that available prior to the introduction of the ANTS reforms (Freebairn 2002; Commonwealth of Australia 2008a).

\section{Expenditure Pressures: The public-hospital funding debate}

While it is not possible to provide a comprehensive analysis of the expenditure pressures currently confronting State governments, the next section of the paper

\footnotetext{
${ }^{2}$ While the national housing market experienced a temporary revival in 2007, preliminary data for the first quarter of 2008 suggests that higher interest rates are starting to bite. While prices of established dwellings remain steady, the fact that sales volumes have fallen by up to 30 per cent in some States does not bode well for property-tax revenue (ABS 2008).

3 The NSW Government's controversial proposal to privatise $\$ 21$ billion-worth of electricity assets has always been closely linked to the need to invest a $\$ 110$ billion in infrastructure of the next decade (Ferguson 2007).
} 
will provide insights into one of the main financial pressure points in the Australian federation; funding public hospitals.

A significant trend in Australian public finance in recent years has been for the States to fund a greater proportion of Australia's public-hospital system despite the fact that the States have the weakest revenue base. This is particularly significant given that health-care costs are growing faster than either GDP or revenue across the developed world. In the case of the Australian public-hospital system, according to the Australian Institute for Health and Welfare (AIHW) total funding has increased at 12 per cent per annum in nominal terms in the decade to 2005-06 (AIHW 2007). This is despite the fact that there has been increased utilisation of the private hospital system owing to the Commonwealth's private health insurance rebate (at a cost of $\$ 3$ billion per annum) and growing recognition that this level of funding is inadequate (AMA 2007). In short, the States have been shouldering a greater share of the public-hospital funding burden, a share which will have to increase significantly in order to improve the quality of key health services.

Figure 2: Funding sources for Australian public hospitals (current prices) 1995-96 to 2005-05

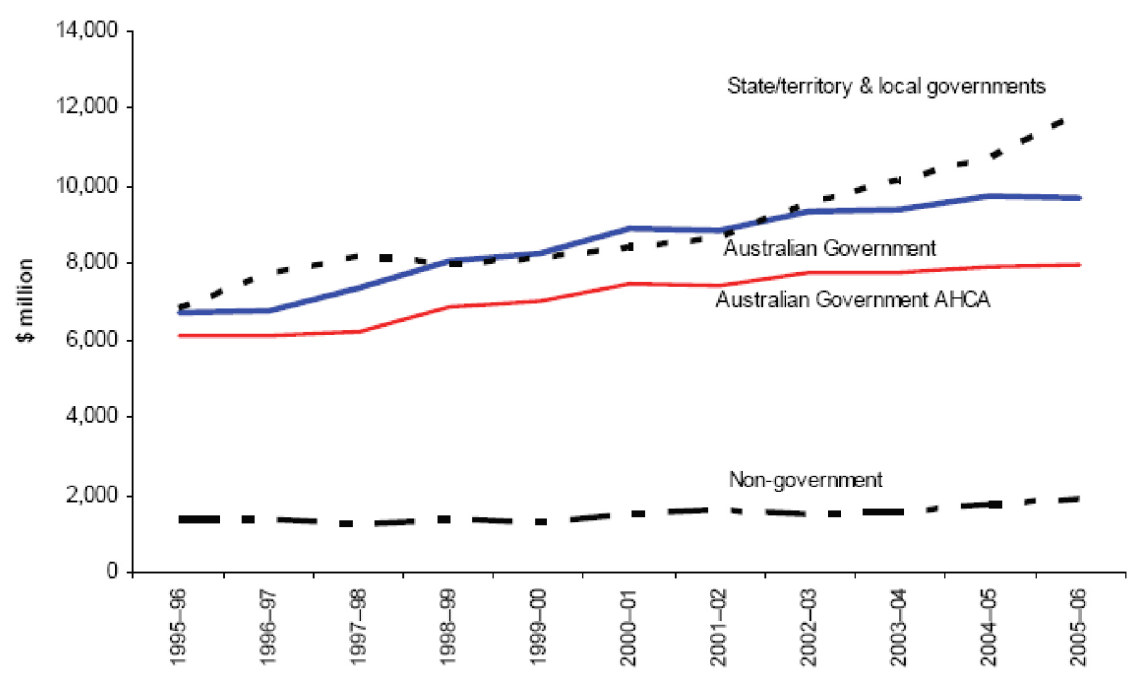

Source AIHW (2007: 55) Note: The upper line representing 'Australian Government' funding is inclusive of specific Australian Healthcare Agreement (AHCA) funding.

In absolute terms, State governments have increased public-hospital funding by between $\$ 1$ billion and $\$ 1.6$ billion per annum over the past three years (AIHW 2007: 55). Beyond this, State governments have argued that they require an additional $\$ 1.5$ billion per annum to adequately fund the public-hospital system (Queensland Government 2007). While this represents only one of the 
funding pressures confronting State governments, the growing revenue needs of public hospitals alone consumed 90 per cent of the GST growth dividend in the most recent year for which data is available. ${ }^{4}$ Given the fact that the growth in hospital costs (12 per cent per annum) has exceeded GST revenue growth (8.9 per cent per annum) over the past five years by 3 per cent per annum, it seems inevitable that despite the IGA the public finances of State governments are going to come under increasing pressure.

\section{Reforming federalism: Issues and objectives.}

This loss of fiscal independence has theoretical as well as policy and financial implications. Firstly, the centralisation of fiscal control implicit in the IGA runs contrary to the federalist ideal and the associated principle of financial subsidiarity, or the notion that taxing and spending decisions should be devolved to the level of government closest to citizens (Bird and Ebel 2006). Whilst there are ongoing debates about the relative political and economic merits of fiscal decentralisation (discussed below), it is clear that the IGA has reduced the potential for such devolution and inter-State variation in tax systems and rates.

The growing centralisation in Australian federalism under the IGA has also had a number of political and economic consequences. Arguably, the political authority of State governments has increasingly been constrained in key policy arenas such as education, health and water management, where they either require direct funding and/or cooperation from the Commonwealth. This has both eroded political accountability in Australia's federal system and has forced State governments to accede to Commonwealth demands in areas where States have traditionally had jurisdiction (for example, National Water Initiative; Mersey Hospital takeover).

Given that this paper is fundamentally concerned with intergovernmental financial relations it is important to briefly sketch established arguments concerning whether taxing powers should be centralised or devolved, and the related debate as to whether taxing powers and spending obligations ought to be aligned; the so-called vertical fiscal balance in a federal system.

\section{Arguments for fiscal decentralisation}

First and foremost is the idea that decentralisation will promote tax competition between States, acting as a constraint on revenue growth and providing incentives to improve the efficiency of State taxation. The so-called Tiebout hypothesis is popular with those on the right with an interest in constraining the size of the state while being criticised by those on the left who hold a more sanguine view of the state's ability to provide public goods (Tiebout 1956). A

\footnotetext{
4 Between 2004-05 and 2005-06, GST revenue growth to the States was \$1.83 billion. Over the same period, additional State funding to public hospitals was $\$ 1.63$ billion.
} 
related argument concerns the potential for innovation and interstate policy learning in a federal system. Thirdly, it is claimed that fiscal decentralisation can provide scope for State governments to tailor tax levels and the structure of State tax systems to meet specific regional needs.

\section{Arguments for fiscal centralisation}

There are also a number of arguments for fiscal centralisation. As national economies are exposed to increasing competitive pressures and commerce is increasingly conducted on a national and international scale, there have been growing calls for greater regulatory harmonisation (BCA 2007; Rudd 2007). In the tax arena it is argued that a national tax system reduces compliance costs for businesses operating across State boundaries as well as for consumers and employees who purchase goods and services or work interstate. Harmonisation also eliminates the potential for tax-related distortions caused when taxpayers try to exploit arbitrages between States. On the administrative front, there are also clear economies of scale when tax administration is managed by a national agency such as the ATO on a uniform national tax base.

\section{Vertical fiscal balance and financial accountability}

Another important theme in debates on fiscal federalism concerns the constitutional attribution of taxing powers and spending responsibilities in a federal system. Australia currently has the highest VFI of any federal state in the OECD (Twomey and Withers 2007: 37). There exists a consensus that the delivery of public services is both more efficient and transparent when there is a balance of taxing and spending powers within a federation (Mathews and Grewal 1997; Fitzgerald 1998; World Bank 2000:117; Row and Duhs 2001: 61-3; for a summary, see Dollery 2002). ${ }^{5}$ Yet while most commentators regard Australia's VFI as problematic, there is much less consensus about how it should be resolved.

Federalists argue that the VFI should be addressed by increasing the States' fiscal capacity through expanding their own-source tax base. At the very least it is argued that States need access to an earmarked percentage of national taxes under a regime which grants the States some control over the amount of revenue raised and how it is spent (Warren 2006: Ch. 2). In contrast, centralists argue that the most efficient strategy to address a VFI is for the national government to assume responsibility for the provision of services equivalent to its financial resources.

In between the two ends of this spectrum there are a number of intermediate positions. The most interesting compromises in this respect are funding models

\footnotetext{
${ }^{5}$ Dollery (2002) points out that Groenewegen has long argued that high levels of fiscal centralisation in a federal system tend to decrease administrative and compliance costs (Groenewegen 1990).
} 
which feature a national tax base and centralised administration while preserving the budgetary and governance capacities of sub-national government. For example, in both Germany and Canada, sub-national governments share significant tax bases (such as personal income tax) with national governments (Braund 2003). In practice this involves regional governments setting a surcharge on national taxes which is collected by the central government on their behalf. The goal here is to enhance the efficiency of the national tax system while preserving key aspects of the federalist ideal.

Another option of direct relevance to the Australian debate is for the national government, given its superior budgetary capacity, to assume financial responsibility for key services hitherto managed by the States, but under a governance model which promotes local management and control. The final section of this paper assesses the financial implication of one such transfer; a Commonwealth takeover of public hospitals.

\section{Reforming Fiscal Federalism: Challenges and Opportunities}

The most likely response to the growing financial pressures confronting the States will be a steady increase in tied Commonwealth assistance. Indeed, the forward estimates in the 2008-09 Federal Budget forecast SPPs (Special Purpose payments) to increase from $\$ 32.2$ billion (2007-08) to $\$ 36.9$ billion in 2011-12 (Commonwealth of Australia 2008b). In the crucial issue of health funding, the Rudd Government's four-year National Health and Hospitals Reform Plan will increase public-hospital funding by $\$ 2$ billion (subsequently increased to $\$ 3$ billion over five years in May 2008) so long as the States meet a range of specific reform targets (ALP 2007). While the initiative will help address the current shortfall being experienced by the States, the funding is unlikely to meet the increasing costs associated with running the hospital system unless massive efficiency savings can be achieved (Wells 2007; House of Representatives 2006).

In many ways, the National Health and Hospitals Reform Plan and the associated National Health and Hospitals Reform Commission are a template for the Rudd Government's new federalism agenda, which aims to create a culture of intense collaboration between the Commonwealth and State Labor governments (Kelly 2007). ${ }^{6}$ It appears that the recently elected Labor Government is genuinely committed to grant the States the independence to choose the means by which they improve service delivery. However, the Commonwealth seems much less willing to negotiate when it comes to establishing the goals of intergovernmental reforms. For example, in the Hospital Reform Plan it is quite clear that if the States fail to achieve agreed targets then the Commonwealth will give

\footnotetext{
${ }^{6}$ Prime Minister Rudd's first meeting with the Premiers in December 2007 established intergovernmental working groups for health, productivity, climate change and water, infrastructure, business competition, housing and indigenous affairs. The goal is to rationalise the 90 existing SPP into funding agreement per policy area. (Metherell 2007; Commonwealth of Australia 2008).
} 
consideration to a federal takeover of public hospitals (ALP 2007). Similarly, in education, the Rudd Government is taking an uncompromising position in promoting a national curriculum and uniform learning benchmarks despite the likelihood that this approach will result in conflict with State Labor governments. While the Rudd Government may have the skill and commitment to negotiate significant intergovernmental reforms, history indicates that there are real limits to partisan loyalties and it is likely there will be serious political conflicts between State Labor Premiers and the Federal Labor Government (Hamill 2006: 172-3). Or, as Greg Craven (2008) commented recently, 'COAG necessarily is a creature of stitches and patches. If we are going to approach some of the big issues of federalism, some heavy constitutional weaving will be required.'

Ultimately, cooperative federalism can only work when the States and the Commonwealth have shared interests. When these interests differ, the nature of the VFI in the Australian federation and the system of tied funding which it yields will inevitably result in cost shifting, accountability problems and intergovernmental conflict. Given these structural problems with Australian federalism, more fundamental reforms may be necessary.

\section{Transferring Public Hospitals}

As a result of the cost pressures and complex intergovernmental issues surrounding public hospitals it's not surprising that recent proposals to reform health services have focused on health funding. Perhaps the most significant and ambitious of these is the Rudd Government's National Health and Hospitals Reform Plan. While the plan aims to achieve a negotiated approach to improving the performance of Australia's public hospitals, the Federal Labor party has also expressed an intention to initiate a process whereby the Commonwealth would assume control of Australia's 750 public hospitals by mid-2009 if the States have not implemented the Reform Plan and its associated goals (ALP 2007). ${ }^{7}$ A central question for this paper is how much such a transfer would cost the Commonwealth and how it would impact on intergovernmental financial relations in Australia.

According to the most recent AIHW (2007: 55) report into Health Expenditure in 2005-06, total public spending on public hospitals was $\$ 22.4$ billion, of which the Commonwealth contributed $\$ 10.1$ billion (under the National Healthcare Agreement and other SPPs), with the States contributing \$12.3 billion. If the Commonwealth were to assume responsibility for public hospitals then the States could almost afford to relinquish all of their remaining non-hospital SPPs (\$14.7

\footnotetext{
${ }^{7}$ It must be noted that, away from heat of the election campaign, the federal Health Minister, Nicola Roxon, has been talking down the likelihood of the Commonwealth assuming control of public hospitals (Alexander 2008).
} 
billion for 2005-06), given the \$12.3 billion saved from existing hospital funding commitments.

Table 4: Net financial implications of public-hospital transfers (based on 2005-06 AlHW Data)

\begin{tabular}{|l|l|}
\hline Commonwealth & $+\$ 14.7$ billion (savings through cancellation of SPP to States) \\
\hline & $-\$ 12.3$ billion (assuming the States' share of $\mathrm{PH}$ funding) \\
\hline Net impact & $+\$ 2.4$ billion (in favour of the Commonwealth) \\
\hline
\end{tabular}

While there is clearly a shortfall of $\$ 2.4$ billion for 2005-06, it is important to note that the cost of running public hospitals is rising more rapidly than either revenue growth or other budget expenditures; so it is likely that if a review of public-hospital funding were to be considered in 2009, relinquishing SPP in return for the Commonwealth taking control of public Hospitals would be financially viable. As hospital costs increase, the States could be major financial beneficiaries of such a transfer (Productivity Commission 2005). So while centralised control of public hospitals would clearly offend the principle of subsidiarity and its normative commitment to decentralisation, in other important respects such a proposal has considerable merit. It would improve Australia's VFI and would eliminate the traditional cost and blame-shifting between Federal and State governments associated with both funding public hospitals and health policy more generally. Moreover, if the States agreed to relinquish SPPs as part of the transfer then it would enhance their political and financial independence over those areas where they retained political control.

\section{Conclusion}

This paper asked whether the 1999 IGA has succeeded in putting State public finances on a more sustainable footing. It argues that while GST revenues have increased at a rate of 8.9 per cent per annum in nominal terms over the period, a combination of the parlous condition of the States' remaining own-source taxes and the rapidly increasing expenditure pressures mean that the States are under increasing financial pressure. Given this situation, the second half of the paper sketched one proposal to reform Australian fiscal federalism. The Rudd Government's proposal to assume financial responsibility for Australia's 750 public hospitals has three clear advantages. Firstly, it would resolve the myriad cost-shifting and accountability problems which have afflicted federal-state relations in the area of health policy. Second, it would help restore the fiscal balance in the Australian federation by assigning the area of fastest public-expenditure growth to the level of government with the greatest fiscal capacity. Finally, at a political level, the health-reform agenda seems to be gathering momentum and there is a growing willingness among State and Federal governments to consider radical reform proposals such as transferring responsibility for public hospitals to the Commonwealth. Only time will tell if 
such an initiative becomes a defining achievement of the Rudd Government's first term.

\section{References}

ABS 2007, 'Taxation Revenue 2005-06' (5506.0), Australian Bureau of Statistics, Canberra.

ABS 2008, 'House Price Indexes: Eight Capital Cities' (6416.0), March, Australian Bureau of Statistics, Canberra.

AIHW 2007, 'Health Expenditure Australia 2005-06', Australian Institute of

Health and Welfare, Canberra, at: http://www.aihw.gov.au/publications/ index.cfm/title/10529

Alexander, C. 2008, 'Health System and Renovator's Dream', The Australian, 8 May 2008.

AMA 2007, Public Hospitals Report Card, Australian Medical Association, at: http://www.ama.com.au/web.nsf/

BCA 2007, A Charter for a new federalism, Business Council of Australia, Melbourne, at: <http://www.bca.com.au/Content/101308.aspx>

Bird, R. and Ebel, R. 2006, 'Subsidiarity, Solidarity and Asymmetry' ITP Working Paper 509, Toronto.

Braun, D. 2003, Fiscal Policies in Federal States, Ashgate, Aldershot.

Collins, D. and Warren, N. 2006 'The States and the GST: Demystifying Australian Federal/State financial arrangements', Australian Tax Research Foundation, Sydney.

Commonwealth of Australia 2007, Budget Paper no.3: Federal Financial Relations 2007-08, at: http://www.budget.gov.au/2007-08/bp3/html/index.ht

Commonwealth of Australia 2008a, 'The architecture of Australia's Tax and Transfer System' at: http://taxreview.treasury.gov.au/

Commonwealth of Australia 2008b, Budget Paper no.3: Federal Financial Relations 2008-09, at: http://www.budget.gov.au/2007-08/bp3/html/index.ht

Costello, P. 1998, 'A New Tax System', media release, 13 August 1998.

Costello, P. 2004, 'Doorstop interview', 24 March 2004.

Craven, G. 2008 'Time right to fix federalism', Australian Financial Review, 12 April 2008.

Dollery, B. 2002, 'A Century of Vertical Fiscal Imbalance in Australia', History of Economics Review 36.

Ebrill, L. et al. 2001, The Modern VAT, IMF, Washington DC. 
Eccleston, R. 2004, The Thirty Year Problem: The politics of Australian Tax Reform, The Australian Tax Research Foundation, Sydney.

Ferguson, A. 2007, 'State ponders the $\$ 21$ billion appeal of privatisation', The Australian, 8 September 2007.

Fitzgerald, V. 1998, 'Tax Reform and Federal-State Financial Relations', Quarterly Bulletin of Economic Trends 3.

Freebairn, J. 2002, 'Opportunities to Reform State Taxes', Australian Economic Review 35(4): 405-22.

Groenewegen, P. 1990, Public Finance in Australia (3 ${ }^{\text {rd }}$ ed.), Prentice-Hall, Sydney.

Hamill, D. 2006, The Impact of the New Tax System on Australian Federalism, The Australian Tax Research Foundation, Sydney.

House of Representatives 2006, Inquiry into Health Funding, at: http://www.aph.gov.au/house/committee/haa/healthfunding/report.htm

Kelly, P. 2007, 'The Rudd Agenda', The Australian, 22 December 2007.

Mathews, R. and Grewal, B. 1997, The Public Sector in Jeopardy: Australian Fiscal federalism from Whitlam to Keating, Melbourne: Centre for Strategic Economic Studies, Victoria University of Technology.

Productivity Commission 2004, First Home Ownership, at: http://www.pc.gov.au/inquiry/housing/docs/finalreport

Productivity Commission 2005, Economic Implications of an Ageing Australia, at: http://www.pc.gov.au/study/ageing/docs/finalreport

Queensland Government 2007, State and Territory Concerns in Relation to the $A H C A$ at: http://www.health.qld.gov.au/publications/ aust_hlth_care_agreement/

Row, R. and Duhs, A. 2001, 'The National GST and Commonwealth-State Financial Relations: A Neglected Issue', Economic Analysis and Policy 31(1).

Rudd, K. 2007, 'Facing the Future - An address to the National Press Club', at: http://www.alp.org.au/download/070417_sp_npc.pdf

Smith, G. 2007, 'Australia's Aggregate Tax Burden', The Australian Tax Research Foundation, Sydney.

Tiebout, C. 1956, 'A pure theory of local expenditures', Journal of Political Economy 64.

Twomey, A and Withers, G. 2007, Australia's Federal Future, Federalist Paper 1, A Report for the Council for the Australian Federation. 
Warren, N. 2006, Benchmarking Australia's Intergovernmental Fiscal Arrangements — Final Report, at: http://www.treasury.nsw.gov.au/_data/assets/ pdf_file/0006/5793/fin-bench-rep.pdf

Wells, R. 2007, 'Rudd's Hospitals Takeover - Read the fine print', at: http://www.crikey.com.au/Politics/20070824-Hospitals-takeover-Read-thefine-print.html

World Bank 2000, World Development Report 1999-2000, Oxford, Oxford University Press. 